\title{
Communication on Sciences Framework: an interview with Robert K. Logan
}

\section{Adriana Braga}

\section{Abstract}

In this exclusive interview for E-Compós, Dr.

Logan tells about his career, his collaboration

with Marshall McLuhan, Communication

Theory and interdisciplinary approaches to

Communication Sciences.
Adriana Braga I adrianabraga1@yahoo.com.br

Professora do Programa de Pós-Graduação em Comunicação Social da Pontifícia Universidade Católica do Rio de Janeiro (PUC-Rio). Pesquisadora do Conselho Nacional de Desenvolvimento Científico e Tecnológico (CNPq).
Robert K. Logan is Professor Emeritus in Physics at the University of Toronto and Chief Scientist of Strategic Innovation Lab at the Ontario College of Art and Design.

He has a variety of experiences as an academic involved in research in complexity theory, information theory, biology, environmental science, linguistics, industrial design and media studies. He is also a Senior Fellow at the Origins Institute, McMaster University and also at the Institute of Biocomplexity and Informatics, University of Calgary.

He published with and collaborated with Marshall McLuhan. He was also active in the business world as the founder of companies engaged in computer training, Web development and knowledge management. He was active in politics from 1974 to date. Among his many activities he served as an advisor to PM Pierre Eliot Trudeau, policy chair of the Ontario wing of the federal Liberal Party and an advisor to various federal cabinet ministers. He is also an author or editor of 11 books, several book chapters and many 
articles in refereed journals. Since 2010, he is a member of the Editorial Board of E-Compós.

In this exclusive interview for E-Compós, Dr. Logan tells about his career, his collaboration with Marshall McLuhan, Communication Theory and interdisciplinary approaches to Communication Sciences.

\section{Adriana Braga: Professor Logan, you are} a renowned scientist in Physics, and at the same time, you have an expressive work on Communication Theory. Can you tell us about your career and how did you come to relate these apparently distant areas?

Robert K. Logan: I taught a course for humanities students entitled the Poetry of Physics - I explained the ideas of physics without math. That led to McLuhan inviting me to have lunch with him from which o ur first article together grew. Here is how it happened. I was organizing a seminar, The Club of Gnu on future studies at New College, University of Toronto in 1974 and recruited Prof. Arthur Porter an industrial engineer. He called Marshall to invite him to join us and mentioned my name. McLuhan had heard about my course the Poetry of Physics and the Physics of Poetry and instructed Porter to send me over to the coach house to have lunch with him. I was very excited to be having lunch with such a famous guy. We lunched at the faculty cafeteria at St. Mike's and as soon as we sat down with our trays McLuhan immediately asked me what I had learned by teaching the Poetry of Physics. I explain that I was fascinated by the problem posed by Joseph Needham in his book the Grand Titration of why abstract science began in the West despite the fact that so much of technology originated in China. I proposed that since monotheism and codified law were unique to the West and that together they give rise to a notion of universal law that this might explain the Needham paradox. Marshall McLuhan nods his head in agreement and then asks me pointedly what else do we have in the West that is not present in China. I am totally intimidated by this guy who seems to be talking to me at 100 mile per hour. I can't think and finally I say, "I give up." He smiles and says the alphabet of course.

I let out the loudest groan because I immediately see where he is going as I recall that he showed the connection of the alphabet with abstract science and deductive logic in The Gutenberg Galaxy and Understanding Media. It all becomes so obvious - the alphabet serves as a model for analysis, classification, coding and decoding. To use the alphabet to write one must analyze each word into its basic phonemes and them represent each phoneme with a meaningless visual sign, a letter of the alphabet. So writing with an alphabet is coding sounds into visual signs and reading an alphabetic text is decoding the visual signs back into sounds. As far as classification goes the alphabet allows every word and every name to be ordered alphabetically as is the case in a dictionary.

Taken altogether the alphabet promotes codification, classification and analysis the basic skills needed for abstract science and deductive logic. Realizing that our independent explanations for the rise of abstract science in the West complemented and reinforced each other, we combined our ideas and developed the 
hypothesis that the phonetic alphabet, codified law, monotheism, abstract science and deductive logic were ideas unique to the West.

All of these innovations, including the alphabet, arose within the very narrow geographic zone between the Tigris-Euphrates river system and the Aegean Sea, and within the very narrow time frame between 2000 B.C. and 500 B.C. We did not consider this to be an accident. While not suggesting a direct causal connection between the alphabet and the other innovations, we would claim, however, that the phonetic alphabet (or phonetic syllabaries) played a particularly dynamic role within this constellation of events and provided the ground or framework for the mutual development of these innovations.

The effects of the alphabet and the abstract, logical, systematic thought that it encouraged explain why science began in the West and not the East, despite the much greater technological sophistication of the Chinese, the inventors of metallurgy, irrigation systems, animal harnesses, paper, ink, printing, movable type, gunpowder, rockets, porcelain, and silk. Credit must also be given to monotheism and codified law for the role they played in developing the notion of universality, an essential building block of science.

Almost all of the early scientists, Thales, Anaximander, Anaximander, Anaxagoras and Heraclitus, were both lawmakers in their community and monotheistically inclined. They each believed that a unifying principle ruled the universe.

Right then and there at our first meeting in the faculty cafeteria we decided to write up these ideas and publish them as a research article. During this whole conversation I was taking notes. McLuhan was only talking. At a certain point in our discussion he said to me please write up these ideas and we can discuss them further. As soon as I left that luncheon I went home and wrote up the ideas we had discussed. I remember being very nervous because I was not sure how McLuhan would take to the notion that the phonetic alphabet had helped the Hebrews to conceive of the notion of monotheism and the existence of God. I was worried this might offend McLuhan's Roman Catholic sensibilities. I needn't have worried. He was fine with the idea and basically accepted the paper largely as I had written it. As I read it to him while he lay on his couch or day bed, he would ask me to change a phrase here and a word there. He amplified a couple of points that were being made in the paper but basically accepted the document as I had read it to him. He also suggested the title, Alphabet, Mother of Invention (McLuhan \& Logan 1977). Once he was finished making his suggestions he asked me to give the hand written manuscript with his additions to his secretary Marg Stewart to be typed up. He sent the paper to Neil Postman, who was the editor of Etcetera, the journal of the International Society of General Semantics. The paper was accepted and Neil Postman sent a note declaring it was the best paper McLuhan had written from a left-brain point of view. I had written up our paper that first night after our luncheon discussion as though I was writing a physics paper.

Adriana Braga: In your oppinion, which 
contributions Physics and Communication Science can offer each other?

Robert K. Logan: I used complexity theory from physics to explain the evolution of language from speech to writing and math to science to computing to the Internet in my book The Sixth Language. Here is how I connect physics and communications which will take quite a bit of text to explain.

The Evolution of the Six Modes of Language

The development of language is the one characteristic of Homo sapiens that distinguishes it from all other species. All species communicate, as the behavior of bees, birds, and primates demonstrates. No other species, however, has created such a perfect tool for abstract thinking as language. I believe that verbal language in the form of speech arose out of the need of pre-human hominids to conceptualize. The world of hominids became progressively more complex as they acquired the capability for tool making, for controlling fire, for the social intelligence needed to live in large groups to share the advantages of fire, for large scale co-ordinated hunting, and for mimetic communication or signaling through gestures, hand signals, body language, and non-verbal vocalization.

The chaos that emerged with this complexity gave rise to a new level of order in the form of spoken language which represents in terms of Prigogene's theories of chaos and complexity a bifurcation from non-verbal to verbal language and communication. It also represents a bifurcation from percept based thought to concept based thought or conceptualization.
I believe that all of the hominid skills iterated above from tool making to mimetic communication were percept based and that the emergence of concepts in the form of words increased the chances for survival of those hominids that could verbalize their thoughts and hence conceptualize. The first concepts were words which served as both metaphors and strange attractors for certain sets of percepts. The word water united all the experiences with water whether it was drunk, bathed in or fell as rain. This transition from percept to concept based thinking and from non-verbal to verbal language also represented the transition or bifurcation from pre-human hominids to full blown human beings, Homo sapiens sapiens. The hominid brain was basically a percept processor but with language it bifurcated into the human mind that could conceptualize and process abstract information. The mind is the brain plus language. This line of thinking justifies one of the basic assumptions of this study, namely, that language is more than just a communications system - it is also an informatics tool. It also ties in with Vygotsky's hypothesis that the evolution of speech is connected with the use and manufacture of tools and the growth of the brain-case. "Biological evolution ties in with the growth of culture, since the use of language seems obviously associated with habitual tool use (limiting the use of gestures) and with increasing human intelligence" (Vygotsky 1962).

The two principle uses of speech are for abstracting experience through conceptualization and communication. In preliterate societies speech was the medium for social interactions and a tool 
for the coordination of activities that require cooperation, such as hunting or food gathering. Spoken language evolved more complex functions and was used in the cultural apparatus of a society to tell tales and sing songs. Eventually, speech was used as a medium to record (or store) and retrieve cultural information in the form of poems, folktales, and folk songs. As stories became more complex, speech was used to organize the information stored in these formats. Organizational forms such as rhyme, rhythm, meter, and plot, in turn, became information tools which permitted larger amounts of data to be stored and successfully retrieved (Havelock 1963).

Eventually, however, speech and the human capacity for memorization encountered limits as to how much data could be recorded in this manner. Writing systems and numerical notations emerged which allowed the amount and type of data being stored to expand enormously. The invention of writing and mathematical notations also had a tremendous impact on the informatic capacity of human language and thought. Written records gave rise to new forms of classification, analysis, and other forms of information processing. The increase in the informationprocessing capacity that mathematical notations make possible is easily confirmed by comparing the complexity of mathematical calculations that can be done with pencil and paper compared with calculations done solely in one's head.

The increase in the amount and sophistication of data that writing and mathematics made possible eventually gave rise to a new form of language and information processing the language of science. Scientific activity, whether it is concrete or abstract, is confined to literate societies. Science is not just the gathering of new knowledge about nature; it also consists of giving a shape to that knowledge by organizing it systematically. It is a form of knowledge management. The effective storage and information processing that writing and mathematics made possible allowed scholars to gather and collect so much data that the only way to deal with the complexity and the information overload that ensued was to develop a new mode of organization known as the scientific method.

Science and the scientific method, however, also became a tool for generating still more information-gathering activities. The information overload that modern science and the scientific method helped to generate became so great in the twentieth century that it led to the development of computers as a way to help scientists cope with the enormous amounts of data they accumulated and the complex calculations they needed to execute.

Vygotsky's work shows how children discover that language, a medium of communication, can also be used as a tool to process information and solve problems. One can easily extend this notion backwards in time and assume that at some point, humans discovered that their system of vocalized verbal signals could be used internally, as a tool for thinking. It might even be the case that speech arose to make conceptual thinking possible and was then used for communication purposes. And a third possibility is that it emerged simultaneously as both a tool for thinking and a medium for communication. 
The extension of speech and its concretization in the form of writing, mathematics, science, computing, and the Internet leveraged language as a tool for thinking and amplified its informatics capacity while preserving its communications function. The motivation for the emergence of new forms of language, however, seems to have been strictly the need for a greater informatics capacity, not increased communications.

Writing was first used not for communication but for the keeping of accounting records. For the period just after the emergence of writing, "few literary documents [were] excavated, although the same period has yielded tens of thousands of economic and administrative tablets and hundreds of votive inscriptions" (Kramer 1959). The very first words to be assigned a written form in the Sumerian language were the words for agricultural commodities that were collected as tribute by the priesthood who ran the irrigation system. They used writing to record who paid their taxes to the state. Written numerals were invented at the same time as writing to keep track of the amounts of each commodity that were given in tribute.

The invention of writing and abstract numerals illustrates cyberneticist Ross Ashby's "theorem of requisite variety" (Ashby 1957) as well as the notion that necessity is the mother of invention. According to Ashby, managers can only control a system if they can create a model of it which contains the requisite variety or complexity to accurately describe it. The priests running the irrigation system needed to collect tribute from farmers in order to feed the irrigation workers. They therefore needed to store and keep track of a complex set of data. Given that human memory has difficulty coping with more than seven, plus or minus two, elements at a time, the only way the priests could remember who had paid their tribute and who had not was to create permanent records of the tributes. It was only after the invention of writing for the purposes of economic control that writing was also used for the purposes of communication, and eventually, for other informatic applications such as the composition of stories or written poems.

The development of science was also motivated by purely informatic considerations. Abstract science permitted greater control of nature through better organization of information and the ability to make predictions. The scientific method provided scientists with the requisite variety to control a body of knowledge that the languages of writing and mathematics had not been able to manage.

The invention of computing is still another example of informatics driving the development of language. Without computing, natural and social scientists would not have been able to manage the information overload created by their disciplines. It was only after its initial application as an informatics device that computing was also used for communications, and hence, its name in English is "computer" (as in calculator) and not "word processor," even though far more users process words with computers than compute or calculate numbers with them.

The Internet is another example of a new form of language which emerged from an information overload. Computing increased the sheer number of messages that needed to be communicated as 
well as the number of people that needed to be communicated with. As the world shrunk to the dimensions of a global village the number of people in the village with whom one wanted to communicate increased dramatically.

This information overload or traffic jam of messaging gave rise to networking, clientserver systems and finally the Internet. The Internet as opposed to client servers systems was able to embrace the entire global community in a single electronic embrace. As is so often the case a quantitative change created a qualitative change and as a result a new language emerged, the Internet or the sixth language.

Starting with the ability to record ideas through writing and mathematical notation, human thought has become increasingly more complex. The need to model more complex phenomena has driven the development of the six modes of language. Consequently, each new mode of language is informatically more powerful than its predecessors, but at the same time a little less poetic with the exception of the Net which because of its visual and audio elements is able to incorporate the arts and mode of artistic expression. Our model of the evolution of language is one in which the information-processing capacity of language becomes more and more important as the complexity of human thought increases. It is essential to remember, however, that all forms of language possess a dual capacity for communication and information processing. Computers and the Internet are also communication devices and the spoken word has an informatics capacity. Both of these features of language must be addressed when we consider the nature of work and education.

Adriana Braga: For a long time, the academic potential of intertwining different disciplinary fields, sometimes described by terms such as "interdisciplinarity" or "multidisciplinarity" has been argued to be a promising path for Science. On the other hand, in ordinary institutional academic life, there is a strong resistance to academic practices of such kind. For instance, many Departments demand a "pure blood" formation for applicants to research grants and teaching positions, and "indisciplinary" researchers can have their careers slowed down for doing so. As a scientist, you have been working for many years in a Physics Department, but concerned on Communication research interests. How do you evaluate your experience on scientific, political and institutional levels?

Robert K. Logan: The boundaries between disciplines were developed by specialist who as McLuhan said know more and more about less and less until they know everything about nothing. It is only by crossing disciplinary boundaries that we can explain complex phenomena.

Adriana Braga: How do you see contemporary Communication Studies (a young academic field, born on the confluence of several disciplines) on the universe of Science? Robert K. Logan: Communications studies is part of science and science is part of communications. They depend on each other. 
Language", you relate the acquisition of certain technologies as being deeply involved with social transformations (e. g. agriculture giving raise to aristocracy, or literacy creating mid-class). How do you evaluate the transformations in social order that can be brought with the introduction of personal communications mediated by devices such as tablets or smartphones? What would be the "seventh language"?

Robert K. Logan: Everything McLuhan said would happen with electric media happen with digital media but even more so. The seventh language if I have to guess would be social media or maybe Google because Google is a map of the Web. 


\begin{tabular}{|c|c|}
\hline $\begin{array}{l}\text { A Comunicação no quadro das } \\
\text { ciências: uma entrevista com } \\
\text { Robert K. Logan }\end{array}$ & $\begin{array}{l}\text { La Comunicación en el Cuadro de } \\
\text { las Ciéncias: una entrevista con } \\
\text { Robert K. Logan }\end{array}$ \\
\hline $\begin{array}{l}\text { Resumo: } \\
\text { Nesta entrevista exclusiva para E-Compós, o Dr. } \\
\text { Logan conta sobre sua carreira, sua colaboração } \\
\text { com Marshall McLuhan, Teoria da Comunicação } \\
\text { e abordagens interdisciplinares para as Ciências } \\
\text { da Comunicação. }\end{array}$ & $\begin{array}{l}\text { Resumen: } \\
\text { En esta entrevista exckusiva para E-Compós, Dr. } \\
\text { Logan habla cerca de su carrera, su colaboración } \\
\text { con Marshall McLuhan, Teoria de la Comunicación } \\
\text { y abordajes interdisciplinarias para las Ciéncias de } \\
\text { la Comunicación. }\end{array}$ \\
\hline
\end{tabular}




\section{Expediente}

A revista E-Compós é a publicação científica em formato eletrônico da Associação Nacional dos Programas de Pós-Graduação em Comunicação (Compós). Lançada em 2004, tem como principal finalidade difundir a produção acadêmica de pesquisadores da área de Comunicação, inseridos em instituições do Brasil e do exterior.

\section{E-COMPÓS I www.e-compos.org.br I E-ISSN 1808-2599}

Revista da Associação Nacional dos Programas de Pós-Graduação em Comunicação.

Brasília, v.14, n.1, jan/abr. 2011

A identificação das edições, a partir de 2008

passa a ser volume anual com três números.

\section{CONSELHO EDITORIAL}

Afonso Albuquerque, Universidade Federal Fluminense, Brasil Alberto Carlos Augusto Klein, Universidade Estadual de Londrina, Brasil Alex Fernando Teixeira Primo, Universidade Federal do Rio Grande do Sul, Brasil Ana Carolina Damboriarena Escosteguy, Pontifícia Universidade Católica do Rio Grande do Sul, Brasil

Ana Gruszynski, Universidade Federal do Rio Grande do Sul, Brasil Ana Silvia Lopes Davi Médola, Universidade Estadual Paulista, Brasil André Luiz Martins Lemos, Universidade Federal da Bahia, Brasil Ângela Freire Prysthon, Universidade Federal de Pernambuco, Brasil Angela Cristina Salgueiro Marques, Faculdade Cásper Líbero (São Paulo), Brasil Antônio Fausto Neto, Universidade do Vale do Rio dos Sinos, Brasil Antonio Carlos Hohlfeldt, Pontifícia Universidade Católica do Rio Grande do Sul, Brasil Antonio Roberto Chiachiri Filho, Faculdade Cásper Líbero, Brasil Arlindo Ribeiro Machado, Universidade de São Paulo, Brasil Arthur Autran Franco de Sá Neto, Universidade Federal de São Carlos, Brasil Benjamim Picado, Universidade Federal Fluminense, Brasil César Geraldo Guimarães, Universidade Federal de Minas Gerais, Brasil Cristiane Freitas Gutfreind, Pontifícia Universidade Católica do Rio Grande do Sul, Brasil Denilson Lopes, Universidade Federal do Rio de Janeiro, Brasil Denize Correa Araujo, Universidade Tuiuti do Paraná, Brasil Edilson Cazeloto, Universidade Paulista, Brasil Eduardo Peñuela Cañizal, Universidade Paulista, Brasil Eduardo Vicente, Universidade de São Paulo, Brasi Eneus Trindade, Universidade de São Paulo, Brasil Erick Felinto de Oliveira, Universidade do Estado do Rio de Janeiro, Brasil Florence Dravet, Universidade Católica de Brasília, Brasil Francisco Eduardo Menezes Martins, Universidade Tuiuti do Paraná, Brasil Gelson Santana, Universidade Anhembi/Morumbi, Brasil Gilson Vieira Monteiro, Universidade Federal do Amazonas, Brasi Gislene da Silva, Universidade Federal de Santa Catarina, Brasi Guillermo Orozco Gómez, Universidad de Guadalajara Gustavo Daudt Fischer, Universidade do Vale do Rio dos Sinos, Brasil Hector Ospina, Universidad de Manizales, Colômbia Herom Vargas, Universidade Municipal de São Caetano do Sul, Brasil leda Tucherman, Universidade Federal do Rio de Janeiro, Brasil Inês Vitorino, Universidade Federal do Ceará, Brasil Janice Caiafa, Universidade Federal do Rio de Janeiro, Brasil Jay David Bolter, Georgia Institute of Technology Jeder Silveira Janotti Junior, Universidade Federal de Pernambuco, Brasil João Freire Filho, Universidade Federal do Rio de Janeiro, Brasil
John DH Downing, University of Texas at Austin, Estados Unidos José Afonso da Silva Junior, Universidade Federal de Pernambuco, Brasil José Carlos Rodrigues, Pontifícia Universidade Católica do Rio de Janeiro, Brasil José Luiz Aidar Prado, Pontifícia Universidade Católica de São Paulo, Brasil José Luiz Warren Jardim Gomes Braga, Universidade do Vale do Rio dos Sinos, Brasi Juremir Machado da Silva, Pontifícia Universidade Católica do Rio Grande do Sul, Brasil Laan Mendes Barros, Universidade Metodista de São Paulo, Brasil Lance Strate, Fordham University, USA, Estados Unidos Lorraine Leu, University of Bristol, Grã-Bretanha Lucia Leão, Pontifícia Universidade Católica de São Paulo, Brasil Luciana Panke, Universidade Federal do Paraná, Brasil Luiz Claudio Martino, Universidade de Brasília, Brasil Malena Segura Contrera, Universidade Paulista, Brasil Márcio de Vasconcellos Serelle, Pontifícia Universidade Católica de Minas Gerais, Brasi Maria Aparecida Baccega, Universidade de São Paulo e Escola Superior de Propaganda e Marketing, Brasil

Maria das Graças Pinto Coelho, Universidade Federal do Rio Grande do Norte, Brasil Maria Immacolata Vassallo de Lopes, Universidade de São Paulo, Brasil Maria Luiza Martins de Mendonça, Universidade Federal de Goiás, Brasil Mauro de Souza Ventura, Universidade Estadual Paulista, Brasil Mauro Pereira Porto, Tulane University, Estados Unidos Nilda Aparecida Jacks, Universidade Federal do Rio Grande do Sul, Brasil Paulo Roberto Gibaldi Vaz, Universidade Federal do Rio de Janeiro, Brasil Potiguara Mendes Silveira Jr, Universidade Federal de Juiz de Fora, Brasil Renato Cordeiro Gomes, Pontifícia Universidade Católica do Rio de Janeiro, Brasi Robert K Logan, University of Toronto, Canadá

Ronaldo George Helal, Universidade do Estado do Rio de Janeiro, Brasil Rosana de Lima Soares, Universidade de São Paulo, Brasil Rose Melo Rocha, Escola Superior de Propaganda e Marketing, Brasil Rossana Reguillo, Instituto de Estudos Superiores do Ocidente, Mexico Rousiley Celi Moreira Maia, Universidade Federal de Minas Gerais, Brasil Sebastião Carlos de Morais Squirra, Universidade Metodista de São Paulo, Brasil Sebastião Guilherme Albano da Costa, Universidade Federal do Rio Grande do Norte, Brasil

Simone Maria Andrade Pereira de Sá, Universidade Federal Fluminense, Brasil Tiago Quiroga Fausto Neto, Universidade de Brasília, Brasil Suzete Venturelli, Universidade de Brasília, Brasil

Valério Cruz Brittos, Universidade do Vale do Rio dos Sinos, Brasil Valerio Fuenzalida Fernández, Puc-Chile, Chile Veneza Mayora Ronsini, Universidade Federal de Santa Maria, Brasil Vera Regina Veiga França, Universidade Federal de Minas Gerais, Brasil

\section{COMISSÃO EDITORIAL}

Adriana Braga I Pontifícia Universidade Católica do Rio de Janeiro, Brasil Felipe Costa Trotta I Universidade Federal de Pernambuco, Brasil CONSULTORES AD HOC

Édison Gastaldo I Universidade Federal Rural do Rio de Janeiro, Brasil Gisela Grangeiro da Silva Castro, Escola Superior de Propaganda e Marketing, Brasil Helio Kuramoto, Instituto Brasileiro de Informação em Ciência e Tecnologia, Brasil Juliano Maurício de Carvalho, Universidade Estadual Paulista, Brasil Maria Helena Weber, Universidade Federal do Rio Grande do Sul, Brasi Paulo Carneiro da Cunha Filho, Universidade Federal de Pernambuco, Brasil Vera Regina Veiga França, Universidade Federal de Minas Gerais, Brasil EDIÇÃO DE TEXTO E RESUMOS I Susane Barros SECRETÁRIA EXECUTIVA I Juliana Depiné EDITORAÇ̃̃o ELETRÔNICA I Roka Estúdio
COMPóS I www.compos.org.br

Associação Nacional dos Programas de Pós-Graduação em Comunicação

Presidente

Itania Maria Mota Gomes

Universidade Federal da Bahia, Brasil

itania@ufba.br

Vice-presidente

Julio Pinto

Pontifícia Universidade Católica de Minas Gerais, Brasil juliopinto@pucminas.br

Secretária-Geral

Ana Carolina Escosteguy

Pontifícia Universidade Católica do Rio Grande do Sul, Brasil carolad@pucrs.br 